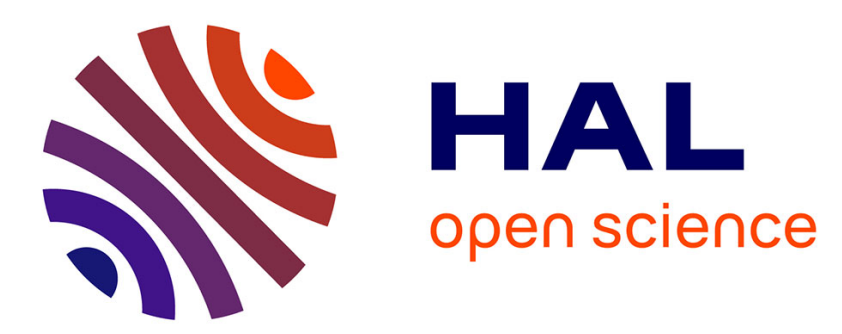

\title{
Regional financial development and bank competition: effects on firms' growth
}

\author{
Joaquin Maudos, Juan Fernandez de Guevara
}

\section{To cite this version:}

Joaquin Maudos, Juan Fernandez de Guevara. Regional financial development and bank competition: effects on firms' growth. Regional Studies, 2009, 43 (02), pp.211-228. 10.1080/00343400701808907 . hal-00516185

\section{HAL Id: hal-00516185 \\ https://hal.science/hal-00516185}

Submitted on 9 Sep 2010

HAL is a multi-disciplinary open access archive for the deposit and dissemination of scientific research documents, whether they are published or not. The documents may come from teaching and research institutions in France or abroad, or from public or private research centers.
L'archive ouverte pluridisciplinaire HAL, est destinée au dépôt et à la diffusion de documents scientifiques de niveau recherche, publiés ou non, émanant des établissements d'enseignement et de recherche français ou étrangers, des laboratoires publics ou privés. 


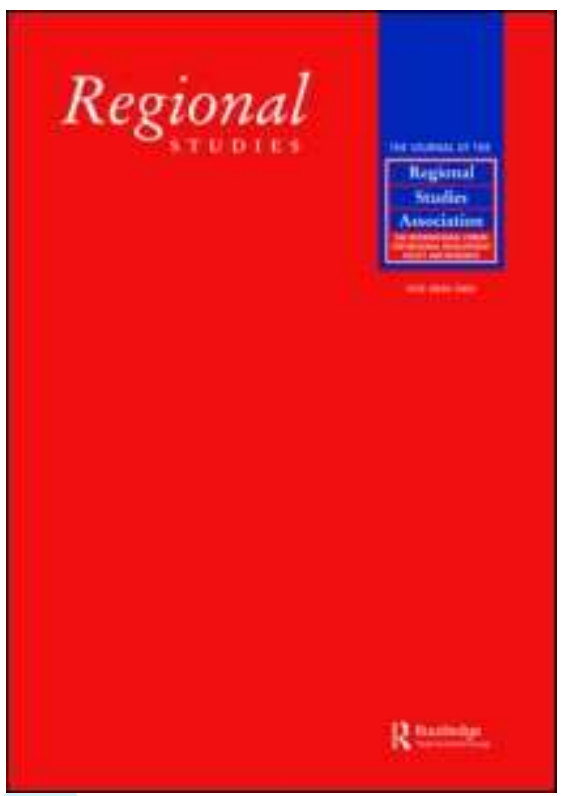

\section{Regional financial development and bank competition: effects on firms' growth}

\begin{tabular}{|r|l|}
\hline Journal: & Regional Studies \\
\hline Manuscript ID: & CRES-2007-0007.R1 \\
\hline Manuscript Type: & Main Section \\
\hline JEL codes: & $\begin{array}{l}\text { D4 - Market Structure and Pricing < D - Microeconomics, G1 - } \\
\text { General Financial Markets < G - Financial Economics, G21 - } \\
\text { Institutions and Services < G - Financial Economics, O4 - Economic } \\
\text { Growth and Aggregate Productivity < O - Economic Development, } \\
\text { Technological Change, and Growth }\end{array}$ \\
\hline Keywords: & economic growth, regional financial development, bank competition \\
\hline
\end{tabular}

\section{SCHOLARONE ${ }^{\text {M }}$ \\ Manuscripts}


Regional financial development and bank competition: effects on firms' growth

\author{
Juan Fernández de Guevara (Ivie \& Universitat de València) \\ Joaquín Maudos (Ivie \& Universitat de València)
}

First: January 2007. Accepted: June 2007

\begin{abstract}
This paper analyzes the effect of regional financial development and bank competition on firms' growth using the Spanish provinces as a testing ground. Our results show that firms in industries with a greater dependence on external finance grow faster in more financially developed provinces. The results also show that bank monopoly power has an inverted-U effect on firms' growth, suggesting that market power has its highest effect at intermediate values. The effect is heterogeneous among firms according to the financial dependence of the industry they belong to. This result is consistent with the literature on relationship banking which argues that bank competition can have a negative effect on the availability of finance for more informationally opaque firms.
\end{abstract}

Key words: economic growth, regional financial development, bank competition JEL: D4, G21, L11

Le développement financier régional et la concurrence bancaire:

l'impact sur la croissance des entreprises.

En se servant des provinces espagnoles en tant que terrain d'expérimentation, cet article cherche à analyser l'impact du développement financier régional et de la concurrence bancaire sur la croissance des entreprises. Les résultats laissent voir que le taux de croissance des industries qui dépendent davantage du financement externe s'avère plus élevée dans les provinces dont le milieu financier s'annonce plus développé. Les résultats laissent voir aussi que le pouvoir monopolistique des banques a un effet sur la croissance des entreprises sous forme d'une U-inversée, ce qui laisse supposer que le pouvoir du marché est à son maximum pour les valeurs intermédiaires. L'effet est hétérogène parmi les entreprises selon leur degré de dépendance financière. Ce résultat est en accord avec la documentation sur les opérations bancaires relationnelles qui affirme l'impact négatif de la concurrence bancaire sur la disponibilité des finances pour les entreprises à caractère opaque quant à l'information.

Croissance économique / Développement financier régional / Concurrence bancaire

Classement JEL: D4; G21; L11 


\title{
Regionale Finanzentwicklung und Wettbewerb zwischen Banken: Auswirkungen auf das Firmenwachstum
}

Juan Fernández de Guevara and Joaquín Maudos

\begin{abstract}
In diesem Beitrag analysieren wir die Auswirkung der regionalen Finanzentwicklung und des Bankenwettbewerbs auf das Firmenwachstum anhand des Testbeispiels der spanischen Provinzen. Unsere Ergebnisse zeigen, dass Firmen in Branchen, die stärker auf eine Fremdfinanzierung angewiesen sind, in finanziell höher entwickelten Provinzen schneller wachsen. Ebenso geht aus den Ergebnissen hervor, dass die Monopolstellung von Banken einen umgekehrten U-Effekt auf das Firmenwachstum ausübt, was darauf schließen lässt, dass die Kraft des Marktes bei mittelhohen Werten am wirksamsten ist. Diese Wirkung fällt unter den Firmen je nach der finanziellen Abhängigkeit der Branche, der sie angehören, heterogen aus. Das Ergebnis ist mit der Literatur über Bankbeziehungen konsistent, in der die These vertreten wird, dass sich ein Wettbewerb zwischen Banken negativ auf die Verfügbarkeit von Finanzen für Firmen mit weniger offenen Informationen auswirken kann.
\end{abstract}

Key words:

Wirtschaftswachstum

Regionale Finanzentwicklung

Wettbewerb zwischen Banken

JEL: D4, G21, L11

Desarrollo financiero regional y competencia bancaria: efectos en el crecimiento empresarial

\section{$\underline{\text { Juan Fernández de Guevara and Joaquín Maudos }}$}

\begin{abstract}
En este artículo analizamos el efecto del desarrollo financiero regional y la competencia bancaria en el crecimiento empresarial usando las regiones españolas como base de prueba. Nuestros resultados indican que las empresas en industrias con una mayor dependencia de finanzas externas crecen más rápido en las regiones con un mayor desarrollo financiero. Los resultados también indican que el poder del monopolio bancario tiene un efecto $\mathrm{U}$ invertido en el crecimiento empresarial lo que indica que el poder del mercado tiene un mayor efecto en valores intermedios. El efecto es heterogéneo entre las empresas según la dependencia financiera de la industria a la que pertenecen. Este resultado coincide con la literatura sobre las relaciones con los bancos que sostiene que la competencia bancaria puede tener un efecto negativo en la disponibilidad de las finanzas para las empresas menos transparentes a nivel informativo.
\end{abstract}

Key words:

Crecimiento económico

Desarrollo financiero regional

Competencia bancaria

JEL: D4, G21, L11 
Instituto Valenciano de Investigaciones Económicas (Ivie), c/ Guardia Civil, 22, Esc. $2^{\mathrm{a}}$, 1', 46020 Valencia (SPAIN). Tel: 34 96.319.00.50, Fax: 34 96.319.00.55. Email: joaquin.maudos@uv.es [corresponding author]; juan.fernadez@ivie.es

Universitat de València, Departamento de Análisis Económico, Edificio Departamental Oriental, Avda. de los Naranjos, s/n; 46022 Valencia (SPAIN). 


\section{Introduction *}

In recent years, we have witnessed a reawakened interest in issues related to economic growth, and in analyzing the importance of the sound functioning of financial institutions as a growth factor. Theories of financial intermediation have demonstrated how intermediaries help to overcome market frictions by reducing the costs of transferring information and wealth between savers and investors. Clearly, when financial systems perform their functions well, the cost of financial intermediation will be lower and economic growth will increase.

The quality of the functions provided by the financial system can be approximated by aggregate measures of financial development. In this respect, "a growing body of work demonstrates a strong, positive link between financial development and economic growth, and there is even evidence that the level of financial development is a good predictor of future economic development" (Levine, 1993, pp. 703).

However, Rajan and Zingales (1998) suggest that the positive correlation normally found between financial development and economic growth may be due to a problem of omitted variable. Given that financial development depends on economies' capacity to save and, according to certain growth models, saving affects the long-run growth rate of the economy, then the observation of a positive relation between financial development and economic growth may be a consequence of the relationship between these two variables and the saving rate. The precise mechanism through which financial development fosters economic growth must therefore be identified.

With this aim, Rajan and Zingales (1998) explore the relevance of the financial sector to find out whether industries with a higher dependence on external finance grow faster in more financially developed countries. Much of the theoretical literature establishes that financial markets and banking institutions help to resolve problems of adverse selection and moral hazard, thereby reducing financing costs. In this way, financial development should help firms or sectors experiencing moral hazard and asymmetric information problems to obtain funds. Rajan and Zingales (1998) propose a test for this hypothesis, under the assumption that sectors with greater dependence on external financing will grow more rapidly when the financial markets they access are more developed. The advantage of this approach is that it specifies one of the mechanisms by which the financial sector affects growth, providing a robust causality test that corrects for country and economic sector effects. 
As well as the importance of financial development, a further subject of interest that has received much less attention is the influence of the degree of bank competition on economic growth. From a theoretical (and also empirical) point of view, the literature on the subject shows ambiguous effects. Thus, on the one hand, the conventional economic theory teaches us that exercise of market power is associated with less credit availability, a higher interest rate and, therefore, lower economic growth. However, on the other hand, some authors argue that where market power exists, banks may have more incentive to invest in the acquisition of soft information by establishing close relationships with borrowers over time (relationship banking), facilitating the availability of credit and consequently reducing firms' financial constraints (Dell'Ariccia and Marquez, 2005). In this scenario, banks can make their investments in client relationships profitable in the long term as a consequence of the existence of an information monopoly (Petersen and Rajan, 1995).

The arguments used to confirm the importance of financial development and bank competition on economic growth are equally valid in an application from a regional perspective. Thus, the existence of major differences in the degree of financial development and bank competition among regions in the same country can help to explain the differences observed in regional growth rates.

As Carbó, López and Rodríguez (2006) point out, the analysis of the relationship between financial development (and bank competition) and growth from a regional perspective (rather than from a cross-country perspective) has several advantages. First, the use of regions within a country implies that institutional, legal, cultural, etc. factors are more adequately controlled, since there are fewer differences among regions than among countries. Second, information on regions (of a specific country) is more widely available and homogeneous than information on countries. And third, the relevant financial market (and therefore, the measurement of financial development and bank competition) is more accurately defined at regional level ${ }^{1}$. Thus, as Carbó et al. (2006) affirm, regional and provincial financial markets have been found to show significant differences in terms of concentration, prices and other competition indicators, which makes them an ideal laboratory to investigate this issue.

In this context, the purpose of the present study is to provide empirical evidence of the effect of financial development and bank competition on economic growth in Spanish firms. The Spanish case provides a good testing ground to analyze these issues because of the significant differences among regions/provinces both in terms of financial development and of the competitive rivalry in the banking markets. 
The main original contributions of this paper are as follows. First, the study combines information at firm level with information on the financial markets in the provinces. Thus, similarly to the study by Guiso et al. (2004), we extend the approach proposed by Rajan and Zingales using a large panel of firm-level data (in our case for Spanish companies). The main advantage of using firm-level data is that they allow us to see whether financial development and bank competition affect firms differently, depending on the size class they belong to. Theoretically, we do not expect all firms to be equally affected by provincial financial development and bank competition, considering that larger firms can raise funds more easily in markets at a distance from their main headquarters. Second, in contrast to other studies that analyze the effect of bank competition on economic growth or on firms' financial constraints, the database we use provides information on the number of bank relationships. Thus, while previous studies measure the competitive rivalry of the banking market in which the borrowing firm has its headquarters, in this case, we can directly measure the market power of the banks the firm actually deals with. Third, as well as using bank market concentration as an indicator of competition, we use a market power indicator from the industrial organization literature -the Lerner index- due to the limitations of structural indicators based on market concentration. Furthermore, the methodological approach used allows us to estimate Lerner indices separately for the loan market, rather than for all banking activity. We can therefore measure more accurately the effect on firm growth of bank market power in setting loan interest rates. Fourth, in contrast to previous studies of the Spanish case, our bank competition indicators take into account all the banking firms competing in the Spanish market, incorporating not only commercial banks into the analysis, but also savings banks and cooperative banks. And fifth, as provincial-level information is available, financial variables are measured for the 52 provinces (NUTS3=provincias in Spain), rather than for the 17 Spanish regional administrative territories (Comunidades Autónomas or NUTS2). The financial development and bank competition indicators for the province in which each firm has its headquarters can therefore be more accurately attributed to individual firms.

The remainder of the paper is structured as follows. In section 2 we review the existing literature on the influence of financial development and bank competition on economic growth. Section 3 describes the model specification and the issues regarding the measurement of financial development, bank market power, external financial dependence and the specification used to analyze the effect of provincial financial development and bank competition on economic growth. Section 4 describes the data, sample and variables used. The main empirical results are provided in section 5 . The summary of the results, conclusions and policy implications are presented in section 6 . 


\section{Related literature}

\section{Financial development and growth}

The capacity of an economy to grow depends on its ability to raise capital accumulation rates, and to use the resulting productive assets more efficiently. Financial intermediation supports this investment process by mobilizing saving to investment. The efficiency of financial intermediation encourages savings and reduces constraints on capital accumulation. As Levine (1997) describes, the impact on economic growth of the functions of the financial system (to produce information ex ante about possible investments; to mobilize savings and allocate capital; to monitor investments; to facilitate the trading, diversification and management of risk; and to exchange goods and services) depends on three characteristics of financial systems: the level (size) of financial intermediation; the efficiency (quality) of financial intermediation; and the composition of financial intermediation.

From an empirical point of view, the seminal work on the link between financial development and economic growth is that of Goldsmith (1969). Using data from 35 countries for the period 1860-1963, he concludes that a parallelism exists between economic growth and financial development over periods of several decades. However, as Levine (1993) points out, Goldsmith's work has certain limitations: a) it does not control for the effect of other variables relevant to explaining growth; b) the proxy variable used to measure the sound functioning of the financial sector has certain drawbacks; and c) the direction of causality is not identified.

During the nineties, various studies provided empirical evidence in attempts to solve the problems presented by Goldsmith's (1969) work. King and Levine (1993a and b) substantially extended the sample of countries, controlled for the influence of other variables affecting economic growth, constructed new indicators of financial development and analyzed their influence on a variety of economic growth dimensions. Their results showed a strong positive correlation between financial development and economic growth indicators, and revealed that initial levels of development are a good predictor of production, capital and productivity growth rates.

Levine and Zervos (1998) investigate whether different measures of financial development predict future growth rates of production, capital, productivity and saving. Their results show a positive and significant correlation between the two groups of variables, even when other explanatory variables were controlled for in the estimation. 
The results indicate that financial markets and institutions provide the services necessary to guarantee long term economic growth.

The work of Levine, Loayza and Beck (2000) evaluates whether the exogenous component of financial intermediation development has an influence on economic growth, and whether differences in the legal and accounting systems among countries explain the differences in their levels of financial development. Their results show that the exogenous component of financial intermediation development is positively associated with economic growth. They also find that differences in legal systems and accounting practices go some way to explaining the differences in financial development among countries. These two results indicate that legal and accounting reforms and the transparency and effectiveness of accounting practices can, in turn, foster financial development and accelerate economic growth. In the same vein, some authors argue that the effectiveness of financial intermediaries and markets in promoting economic growth depends on the institutions set up to implement financial transactions (see a survey in Beck and Levine, 2005). Interestingly, La Porta et al. (1998) find, for example, that the legal system plays a crucial role in determining financial development and growth relationships.

Beck et al. (2000) make an important contribution, not only in their use of dynamic panel estimation, but also because they analyze the relationship between financial development and the sources of growth (productivity growth, physical capital accumulation, and savings).

Related to the finance-growth nexus literature, recent empirical research shows that access to finance is an important growth constraint for firms, especially for SMEs (see the survey by Beck and Demirgüc-Kunt, 2006). In this context, Berger and Udell (2006) propose a complete conceptual framework to analyze SME credit availability issues in which lending technologies are the key conduit through which government policies and national financial structures affect credit availability.

As we outlined in the introduction, the study by Rajan and Zingales (1998) specified the mechanism by which financial development fosters economic growth. Previous studies had simply verified the existence of a positive correlation between the two variables, without establishing the direction of causality. Although King and Levine (1993a) specifically explore this problem of causality and show that the predetermined component of financial development is a good predictor of growth over a period of 10 to 30 years, Rajan and Zingales (1998 and 2001) put forward two arguments that question these results. First, the positive correlation between financial development and 
Guiso et al. (2004) take the European case as a reference to analyze the importance of financial development and financial integration in explaining differences in economic growth using both sector and firm level data. Following the methodology of Rajan and Zingales (1998), their results once again confirm the positive effect of financial development on economic growth. Moreover, these authors use a wide range of simulations to analyze the effects of an advance on the degree of integration in European financial markets, finding a positive effect on economic growth. The greatest effects would take place if a similar level of financial integration were reached in Europe as in the United States, despite the major differences between countries. Countries with weaker financial structures would reap the greatest benefits, while the effects would be more modest in more financially developed countries.

At a regional level, many studies also analyze the importance of regional finance on regional economic growth ${ }^{2}$. Generally, the starting point in this literature is the assumption growth models usually make that financial capital is perfectly mobile among regions and thus does not have a key role in explaining regional growth. Amos and Wingender (1993) conclude from previous literature that financial capital is not perfectly mobile and, hence, financial activity is spatially segmented and interest rates are not necessarily equalized among regions. They also conclude that this does not mean that financial capital is perfectly immobile, as interaction exists among regional and national markets. They find a distinction between locally oriented credit demand from regional firms and households, and nationally oriented credit demand which has access to national financial markets.

The literature classifies the effects of lifting this assumption of perfect capital mobility in three main categories (see Dow and Rodríguez, 1997, for a survey): regional monetary multipliers; interregional financial flows of funds; and regional financial markets. The richest stream of literature on these three categories concerns regional financial markets. Two sub-categories are distinguished within the regional financial 
markets literature. The first deals with the importance of interest rate differentials ${ }^{3}$, while the second focuses on the regional availability of credit ${ }^{4}$.

Given that interest rates and credit availability are two mechanisms through which financial markets affect economic growth, the existence of regional inequalities in these two variables goes some way to explaining the differences in regional growth rates. Furthermore, if we take into account that regional interest rates and credit availability differentials depend on the efficiency of financial institutions ${ }^{5}$ (see Williams and Gardener, 2003) and on the level of competition in regional financial markets, the regional financial development (proxy for the quality of functions carried out by financial institutions, Levine, 1997) and regional bank market power are therefore explanatory variables for the growth of the firms located in these regions, and consequently, for regional economic growth.

Some papers have examined the importance of regional banking conditions for economic performance. Samolyk (1994) analyzes how information costs and regional banking conditions, especially those related to the quality of bank portfolios-the health of the financial market-, influence regional growth at state level in the US through banks' ability to fund local projects. The underlying assumption of why financial funds do not flow across states is that there is a geographic dimension to the informational costs banks face. Amos and Wingender (1993) model the relationship between regional financial markets and regional income depending on which variable, either credit availability or interest rates, is more determinant on regional expenditure. If perfect or near perfect financial capital mobility existed across regions, the availability of local credit supply would not matter for growth, and interest rates would play a key role. But if capital mobility is not perfect, credit availability becomes the key variable for growth. Their empirical results seem to support this latter view.

But even in the presence of perfect capital mobility, the analysis of the financial regional markets and regional growth nexus is important. Dow (1992) analyzes the credit creating behavior of the banking sector in Scotland, a region perfectly financially integrated within a national area. She finds that financial integration may adversely affect the allocation of new credit to a peripheral region, as freedom of capital movement is compatible with credit constraints. Rodriguez-Fuentes (1998) finds that banks influence regional economic growth, as they are not geographically neutral in the allocation of funds across regions.

In the Spanish case, recent studies by Carbó and Rodríguez (2004) and Carbó, López and Rodríguez (2006) are of particular interest. In the first case, these authors 
employ dynamic causality and panel data techniques to find that lending dependence confers banks a special role in promoting regional economic growth. In the second case, Carbó, López and Rodríguez (2006) show that banking sector development and financial innovation in banking positively contribute to regional GDP, investment and gross savings growth.

\section{Bank competition and growth}

Although available empirical evidence shows a positive effect of banking sector size on growth, the evidence on the influence of bank competition is inconclusive. As Cetorelli and Gambera (2001) show, there are theoretical reasons to suggest that the market structure of the banking sector has a non-trivial impact on the process of capital accumulation and, therefore, on economic growth. Thus, on one hand, the traditional argument suggests that departures from perfect competition are detrimental for growth insofar as they are bound to generate inefficiencies in the allocation of mechanisms provided by the credit market. On the other hand, another argument suggests that banks with monopoly power have greater incentives to establish lending relationships with their client firms, thus facilitating their access to credit lines.

As mentioned in Maudos and Fernández de Guevara (2006), the effect of bank competition on economic growth has been analyzed directly or indirectly in two areas of research. In the first case, in the area of relationship lending (see a survey in Boot, 2000), some studies have analyzed the effect of bank competition on the cost of financing and on credit availability, which obviously affects investment and economic growth. In the second case, a small number of studies have directly analyzed the effect of bank competition on economic growth using aggregate sector information for a sample of countries.

One study with major repercussions for the analysis of the effect of bank competition in determining the value of the bank-borrowing firm relationship is that of Petersen and Rajan (1995). These authors develop a theoretical model that demonstrates how when banking markets are competitive, banks have fewer incentives to invest in relationship building and borrowing firms are subject to greater financial constraints. The model was tested empirically with data on SMEs in the USA and shows that firms located in less concentrated markets are subject to greater financial constraints.

In the area of relationship lending, other papers have analyzed the effect of relationship banking on firms' financing constraints by controlling for the influence of bank competition. D'Auria et al. (1999) found that an increase in concentration causes 
an increase in the cost of financing, although the economic impact is very small. Angelini et al. (1998) show that concentration is not a statistically significant variable on financial conditions, in contrast to the evidence offered by Petersen and Rajan (1995).

One issue that has received little attention is whether the results of the effect of bank market power on firm financing constraints obtained in studies of bank-firm relationships are robust to the use of different competition indicators. In this vein, the only exception is the study by Carbó, Rodríguez and Udell (2006) who analyze the effect of bank competition on the financial constraints facing Spanish SMEs. These authors were the first to use a competition indicator from the industrial organization (IO) literature -the Lerner index- as an alternative to traditional measures of concentration. Their results show that the Lerner index is a more consistent indicator of market power, and cast doubt on the validity of relying on concentration measures as proxies of competition in corporate lending relationships.

Using aggregate information for a sample of countries, a few studies have directly analyzed the effect of bank competition on economic growth. Cetorelli and Gambera (2001) extend Rajan and Zingales' (1998) model by introducing bank market concentration as an explanatory variable for growth. Their results provide evidence that bank concentration promotes growth in sectors requiring higher levels of external finance by facilitating credit access to firms, especially younger firms.

Given the limitations on the use of indicators of market concentration to proxy competition, the recent study by Claessens and Laeven (2005) analyzes the effect of bank competition on economic growth using an indicator of competition based on the theory of industrial organization. Specifically, Claessens and Laeven use the results of a previous study in which they calculate the $H$-statistic for 20 countries, though the analysis of its effect on economic growth is limited to 16 countries. Their main conclusion is that the most competitive banking systems can reduce hold-up problems and financial intermediation costs, favoring firms' access to external finance. Furthermore, given the low degree of correlation between the $H$-statistic and market concentration, the indicators of bank market concentration do not help to forecast sector growth.

Finally, also following the approach of Rajan and Zingales (1998), Maudos and Fernández de Guevara (2006) analyze the effect of financial development and bank competition on economic growth using both structural measures of competition and measures based on the new empirical industrial organization perspective. The evidence 
obtained in the period 1993-2003 for a sample of 53 sectors in 21 countries indicates that financial development and the exercise of bank market power promote economic growth. They argue that the latter result is consistent with the literature on relationship lending, which affirms that bank competition can have a negative effect on the availability of finance for companies that are informationally more opaque. Once again, their results cast doubt on the use of market concentration measures as indicators of competition.

\section{Model specification and measurement issues}

\subsection{Model specification}

The reference model for analyzing the effect of provincial financial development and bank competition on firms' growth is based on the specification adopted in Rajan and Zingales (1998) and subsequently expanded in Cetorelli and Gambera (2001), Claessens and Laeven (2005) and Maudos and Fernández de Guevara (2006) to analyze the effect of bank competition on economic growth.

In the initial study by Rajan and Zingales (1998), the specification focuses on analyzing the effect of financial development, and consequently on testing whether the industries most dependent on external finance present higher rates of growth in countries with a higher level of financial development. These authors examine the differential effect of a common level of financial development on different industries within a country. The virtues of the test are a) it looks for evidence of a specific mechanism by which finance affects growth, thus providing a stronger test of causality, and $b$ ) it corrects for fixed country and industry effects.

The expansion of the Rajan and Zingales model to test the effect of the degree of bank competition on growth takes into account the mechanism by which bank competition affects growth, namely through firms' financial dependence. Thus the introduction of the financial dependence variable interacting with the indicator of bank competition allows us to verify whether firms that require higher amounts of external finance grow faster in provinces with more competitive banking markets (or whether they operate with more competitive banks), or whether, on the contrary, higher levels of market power facilitate access to finance for firms that would not have obtained it in highly competitive contexts. Thus, following the specification of Claessens and Laeven (2005) and Maudos and Fernández de Guevara (2006), the model to be estimated is the following: 


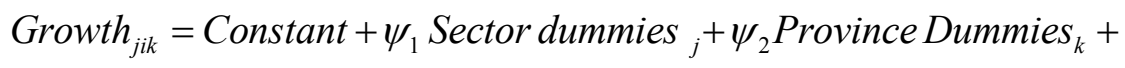

$\psi_{4}$ External Dependence $_{j}{ }^{*}$ Financial Development $_{k}+$

$$
\psi_{5} \text { External Dependence }_{j} * \text { Bank Competition }_{k \text { or } i}+\varepsilon_{j, k}
$$

where $\mathrm{i}=$ firm, $j=$ sector, $k=$ the province in which the firm is located, Growth $=$ the firm's average real sales growth rate, and Bank competition is the indicator of the degree of bank competition in province $k$ (Lerner index or, alternatively, an indicator of market concentration). The sector and province dummies capture the influence of effects specific to each sector or province, respectively.

\subsection{The measurement of financial development}

The three main characteristics of financial systems (the level, efficiency and composition of financial intermediation) that condition the impact of their functions on economic growth are usually proxied by different indicators of financial sector development. Specifically, the indicators that best explain differences in economic growth are: size of bank credit relative to GDP, stock market activity (proxied by the turnover ratio or the ratio of traded value to GDP), and features of the legal system (such as the legal rules and corporate governance activism).

Taking into account the information available for the Spanish provinces, in our case financial development is proxied by one of the most commonly used variables, namely the private credit/GDP ratio. Market capitalization of listed firms and the sum of private credit and market capitalization (as a percentage of GDP) are other frequently used variables to proxy financial development. However, because the securities market is national in Spain, no information is available on market capitalization of firms by regions. As SMEs do not have access to securities markets, we verify our results by splitting the sample into large and small firms. It should also be taken into account that the Spanish financial structure is strongly based on financial intermediaries rather than on markets. Hence, the absence of the market capitalization variable would have less impact on the results than in other countries.

\subsection{The measurement of external financial dependence}

Following the approach in Rajan and Zingales (1998), papers that analyze the effect of financial development on growth measure the external financial dependence at industry level by using the benchmark of a country with developed capital markets in which firms do not face frictions in their access to financing. For the same reason, the external financing needs are computed for large firms, as SMEs face more financial restrictions. 
As Rajan and Zingales (1998) argue, the use of a benchmark is based on the assumption that there are technological reasons why some industries depend on external finance more than others, and that these reasons are the same in all countries (in our case, provinces). Thus, the assumption is that if an industry in a specific province has certain technological characteristics, the same characteristics will be present in the rest of the provinces in the sample analyzed. In other words, we examine whether a firm in a specific industry that is more dependent on external financing grows relatively faster in a province that is more financially developed.

In our case, the financial dependence for each Spanish industry is measured using the information for large firms. We follow the recommendation of the European Commission 96/280/CE to define large firms in terms of the number of employees (firms with more than 250 employees).

Rajan and Zingales (1998) present a measure of external financial dependence on the basis of the flow of investments made by the firm that cannot be financed with the cash flow generated. Because the information available in our database does not permit financial dependence to be calculated in this way, it is proxied by means of balance sheet data. Specifically, the degree of external financial dependence is proxied as the ratio of debt with cost to current liabilities. The definition used is as follows:

$$
\frac{[\text { Non current liabilities }]+[\text { Current liabilities }: \text { loans }]}{[\text { Total assets }]-[\text { Current liabilities }: \text { creditors }]-[\text { Other current liabilities }]}
$$

This ratio may also be expressed as Interest Bearing Debt / [Stockholders' Equity + Interest Bearing Debt] and represents the debt to total capital ratio, excluding accounts payable and accrual liabilities from the numerator and the denominator of the ratio. Expression (2) avoids potential biases in the financial dependence indicator related to trade credit, which is a function of the firm's operations and its contractual relationship with its suppliers.

\subsection{The measurement of bank competition}

In most studies that analyze the influence of bank competition on growth or firms' financing constraints, banking industry competitiveness is proxied by a market concentration index. However, recent studies (Berger et al., 2004; Maudos and Fernández de Guevara, 2004, 2006 and 2007; Fernández de Guevara et al., 2005; Fernández de Guevara and Maudos, 2007; Claessens and Laeven, 2004; Carbó, Rodriguez and Udell, 2006, among others) have demonstrated the limitations of proxying bank competition intensity with concentration measures, and suggest the need 
to use alternative indicators. For this reason, we use a competition indicator from the new empirical industrial organization approach: the Lerner index.

The Lerner index measures the capacity to set interest rates above marginal costs as a proportion of prices. This market power indicator is usually derived from the MontiKlein model, in which under standard assumptions (see Freixas and Rochet, 1997; and Maudos and Fernández de Guevara, 2007), the first order condition of a profit maximization problem yields the following expression for the loan market:

$$
\frac{\left[r_{L}^{*}-r-m c_{L}\right]}{r_{L}^{*}}=\frac{1}{N \varepsilon_{L}\left(r_{L}^{*}\right)}
$$

where $r_{L}$ and $r$ are the interest rates of loans $(L)$ and interbank market, respectively, $m c_{L}$ is the marginal operating costs, $\varepsilon_{L}$ is the elasticity of demand for loans, $N$ is the number of competitors in the market, and the expression of the Lerner index appears on the left hand side of the equation

The estimation of the Lerner index has been applied in studies by Angelini and Cetorelli (2003), Fernández de Guevara et al. (2005 and 2007), Maudos and Fernández de Guevara (2004, 2006 and 2007), Fernández de Guevara and Maudos (2007), Carbó, Humphrey and Rodríguez (2003), Carbó, Rodríguez and Udell (2006), among others. However, only in Maudos and Fernández de Guevara (2006 and 2007) is the Lerner index estimated separately for loans (and deposits) ${ }^{6}$.

Marginal operating costs are estimated from a translog cost function, where operating costs depend on two outputs (loans, and deposits), two input prices (price of labor and price of physical capital) and technical change proxied by a time trend ${ }^{7}$.

In order to test the robustness of results, we also use bank market concentration as an indicator of competition. Specifically, we use the Herfindahl-Hirschman index (HHI), which is defined as the sum of the square of the market shares of all the banks competing in the market. As in other studies referring to the Spanish economy (Carbó, Humphrey and Rodríguez, 2003; Fernández de Guevara and Maudos, 2007; among others), we consider that the regional market (specifically the province) is the most relevant for evaluating competition, given that many financial institutions are in fact present in just one or a few provinces. Since the only information available for each bank at provincial level is the distribution of its branch network, we use this variable as proxy for banking output to calculate the market concentration in each province. 


\section{Data, sample and variables used}

To estimate equation (1), we must combine information on the firm's growth and the financial development and bank competition in the province where the firm has its main headquarters. In the first case, as in Guiso et al. (2004), economic growth is proxied by the annual sales growth rate $^{8}$ on the basis of the SABI (Sistema de Análisis de Balances Ibéricos) database provided by Bureau Van Dijk, which contains financial and economic information for a large sample of Spanish firms. Due to the scarcity of information from 2004 onwards, the period considered runs from 1997 to 2003. However, considering that data is only available over shorter time intervals for many firms, we compute the average annual growth rate for each firm using the available sample for the firm. The growth variable is merged with province level data on indicators of financial development and bank competition and sector level data on financial dependence. Real sales growth rates are computed using the value added deflators for the same sectors of activity (2-digits activity classification from the European industrial activity classification-NACE rev. 1) obtained from Spanish National Accounts.

The information on financial development is proxied by one of the most commonly used variables, namely the private credit/GDP ratio. The information is taken from the Bank of Spain (private credit) and from the National Institute of Statistics (GDP).

Financial dependence is also proxied using information from the SABI database. SABI offers information on the sector of activity to which each firm belongs according to different sector classifications. Specifically, the SABI data used were obtained according to the NACE Rev. 1 classification (59 industries). As in other papers, we restrict our attention to manufacturing firms in order to reduce dependence on regionspecific factors. However, as in Maudos and Fernández de Guevara (2006), we also include the private service sectors of the economy due to their important contribution to the GDP (53\% of the Spanish GDP in 2003). We excluded the financial sector from the services sector. With these criteria, we selected firms from 38 industries.

From data on the large firms, the financial dependence is calculated for each sector, aggregating the firms' data for each year in the numerator and in the denominator of expression (2). Subsequently we obtain the average of the annual data during the period 1997-2003, so that the degree of financial dependence refers to the average for the period. As suggested by Rajan and Zingales (1998), using the average of the data smoothes temporal fluctuations and reduces the effects of outliers. Altogether, for the large firms, information is available for 1,204 firms. 
In the case of the Lerner index, the statistical sources used are the balance sheets and profit and loss accounts of the commercial banks, savings banks and cooperative banks published by the AEB (Asociación Española de Banca), CECA (Confederación Española de Cajas de Ahorros) and UNACC (Unión Nacional de Cooperativas de Crédito $)^{9}$, respectively. The sample includes practically all the financial institutions operating in Spain during the period 1997-2003 (the sample used represents more than $90 \%$ of the total bank assets in Spain, being eliminated only those banks with incomplete information or those considered outliers).

The loan interest rate $\left(r_{L}\right)$ is computed as the ratio of interest income divided by loans. The money market rate is proxied by the annual inter-bank deposit rate. Marginal operating costs are calculated by estimating equation the above mentioned cost function As panel data are available, fixed effects are introduced in the estimation of the costs function to capture the effect of possible unobserved variables specific to each bank

To calculate the indices of market concentration we use the provincial distribution of the bank branch network, as this is the only regional information available at bank level (regional branch distribution in each province.) This information is also supplied by AEB, CECA and UNACC.

The database used to calculate the sales growth rate for each firm (SABI) lists the banks each firm has a relationships with. Consequently, in contrast to other studies that analyze the effect of bank competition on economic growth or on firms' financial constraints, we can measure the market power of the banks with which each borrower has a relationship. In this way, apart from analyzing the effect of the degree of competition in the provincial banking market where the firm has its headquarters, we can also analyze the effect of the market power of the banks each borrower does business with ${ }^{10}$.

We eliminated the firms in the SABI database for which information on the banks they do business with is not available. We also eliminated firms with assets below 500,000 euros (micro firms), due to the inferior quality of their accounting information (see Dechow and Dichev, 2002). In fact, micro firms' annual accounts are only audited in exceptional circumstances, and many of them are simply shell companies, with no trading activity, whose key operations are not typical of a firm providing goods or services. Firms with no information available to calculate any one of the variables required for the estimation were also eliminated. Following these criteria, the final sample totaled 11,142 observations (see table 1) ${ }^{11}$.

$>$ Insert here table $1<$ 


\section{Empirical results}

Table 2 shows the degree of external financial dependence for the different sectors of activity. The sectors presenting the highest level of external financial dependence are "Real estate activities" (0.67), "Renting of machinery and equipment" (0.66), "Air transport" (0.65) and "Land transport" (0.65). The lowest level of financial dependence corresponds to the "Recycling" (0.07), and "Manufacture of motor vehicles" (0.19) sectors.

$>$ Insert here table $2<$

In equation (1), external financial dependence interacts with financial variables to estimate the impact it has on firms' growth. Figure 1 shows the value of the financial development indicator for the Spanish provinces. Specifically, the map classifies the provinces in quartiles according to their level of financial development. Significant differences can clearly be seen among provinces: while the mean value of financial development is 0.71 , the minimum value is 0.44 and the maximum is 1.22 (corresponding to Madrid).

$>$ Insert here figure $1<$

With regard to the bank competition indicators, figure 2 shows the provincial distribution of the Lerner index in the loan market. The value for each province is computed as a weighted average of the Lerner indices of the bank institutions with branches in that province, weighting with the number of branches of each bank ${ }^{12}$. Inequalities among provinces are also confirmed, although they are lower than those found for financial development. Thus, the coefficient of variation is 0.08 in terms of the Lerner index across provinces and 0.20 in terms of financial development. The Lerner index average is 0.33 and the maximum and minimum are 0.39 and 0.28 , respectively ${ }^{13}$.

$>$ Insert here figure $2<$

Provincial differences are sharper in terms of bank market concentration (figure 3 ). Thus, while the average HHI value is 1,390 , the variation interval ranges from a minimum value of 790 and a maximum of 2,406. If we take as our reference the HHI value that USA regulators use to approve or reject a merger (the 1,800/200 rule ${ }^{14}$ ), nine Spanish provinces have HHIs over 1,800, thus revealing a very high bank market concentration.

$>$ Insert here figure $3<$ 
The estimation of the effect of financial development and bank competition on firms' growth is based on equation (1). Initially, we present the results referring to the effect of financial development on economic growth, without including the proxies for bank competition. At the end of each column we provide the estimation of the economic impact associated with financial development and bank competition. Specifically, the last rows of the tables show the differential in real sales growth between a firm belonging to an industry at the $75^{\text {th }}$ percentile level of external dependence and a firm belonging to an industry at the $25^{\text {th }}$ percentile level when the firm is located in a province at the $75^{\text {th }}$ percentile of financial development (bank competition) rather than in one at the $25^{\text {th }}$ percentile (with less financial development and a higher level of competition). Table 3 contains the statistics of the variables used.

$>$ Insert here table $3<$

Column 1 of table 4 shows the results from Rajan and Zingales' basic specification $^{15}$. The coefficient of the interaction term between financial development and financial dependence is positive and statistically different from zero at the $1 \%$ level, indicating that financial development affects growth, particularly in those sectors that rely more heavily on external finance. The differential in real sales growth between a situation of low regional financial development and one of higher development corresponds to approximately 0.55 percentage points of growth in the more financially dependent sectors. This result coincides with prior studies that find evidence to support the hypothesis that financial development facilitates economic growth.

$>$ Insert here table $4<$

The second column shows the results when the effect of bank competition, measured by bank market concentration ( $\mathrm{HHI}$ ), is introduced into the regression. The effect of financial development remains and the coefficient of the interaction term between financial dependence and the HHI is positive but not statistically different from zero.

To check for non-linearity, the third column adds a squared term of the interaction term between financial dependence and bank market concentration. Although the sign of the squared term is positive, it is not statistically different from zero.

If, instead of using the HHI as a proxy for bank competition, we introduce into the regression the Lerner index of the province where the firm has its headquarters (column 4), the effect is negative and statistically significant, implying that greater market power generates lower growth. However, if we check for non-linearity (column 
5), the effect of bank market power on growth is not statistically significant (neither the interaction term nor the squared term is statistically different from zero).

As mentioned above, the SABI database reports the name of the banks with which each borrower has a relationship. This information enables us to compute the mean Lerner index for these banks ${ }^{16}$. Column (6) of table 4 shows that when the interaction term between financial dependence and the Lerner index is introduced into the estimation, the coefficient is not statistically different from zero. However, if the square of the interaction term is included (column 7), we find that bank market power has an inverted-U effect, as the level of the interaction term is positive (and statistically significant) and the squared term is negative (and statistically different from zero). This result coincides with Cetorelli and Gambera (2001) and suggests that the overall growth potential of the firms' sales is highest at intermediate values of market power, since sectors in an intermediate interval of the distribution of external dependence benefit substantially. This is due to the fact that with moderate levels of market power, banking firms capitalize on the advantages derived from investing in lasting relationships with their clients, and can thereby overcome the typical problems of asymmetric information and moral hazard associated with the task of financial intermediation. Therefore, while firms still have to bear higher financing costs, they are faced with fewer restrictions to financing. This greater finance availability is what subsequently leads to higher sales growth. However, once a certain threshold has been crossed, increases in market power are detrimental to firms, as the higher financial costs they face outweigh the advantages associated with greater credit availability ${ }^{17}$.

The magnitude of the total differential effect of bank market power (proxied by the Lerner index of banks that borrowers deal with) on sales growth is positive (0.343 pp.) and statistically different from zero, as the squared term is larger than the level term. Taking into account the non-linear relationship, the maximum effect on growth of the interaction between external financial dependence and bank market power occurs when the value of the interaction term is 0.16 (see figure 4). This value is close to the sample mean (and median) of 0.16 (see table 3), which implies that for a large number of firms (for $50 \%$ of the probability mass of the variable) the value of the interaction term falls within the range in which any increase in the interaction term will involve reductions in their sales growth rate. If we isolate the effect of bank competition, the value of the Lerner index that maximizes the sales growth rate (evaluated as the mean value of financial dependence) is 0.38 , against a mean sample value of 0.39 . As a consequence, once again, firms that maintain relationships with banks whose Lerner index is over 0.38 will grow, ceteris paribus, at a slower rate than firms dealing with banks whose Lerner index value is below 0.38 . If we bear in mind that the value of the 
Lerner index increased in the period analyzed (see Fernández de Guevara and Maudos, 2007), this increase in market power will have prejudiced the growth of a large number of Spanish firms. Obviously, the negative effect of maintaining relationships with banks with high levels of market power will be greater for firms with high levels of financial dependence. Thus, according to figure 4, the annual sales growth may be negative for high financial dependence borrowers dealing with banks with high levels of market power.

$>$ Insert here figure $4<$

Some papers (for example, Petersen and Rajan, 1995) argue that the incentives for monopolistic banks to establish lending relationships with small and medium enterprises (SMEs) are greater, because these firms concentrate their external borrowing from banks and because the problems of asymmetric information between the bank and the borrower are higher. For this reason, we split the sample by size and estimate two separate regressions, for firms with more than and fewer than 250 employees, respectively ${ }^{18}$.

Table 5 shows the results for SMEs. Compared with the results for the whole sample (table 4), all the signs and significance of the estimates remain the same, although the financial development and bank competition indicators have a greater impact. In contrast to SMEs, the effect of financial development and bank competition on sales growth in large firms (table 6) is not statistically significant ${ }^{19}$. These results support the hypothesis that financial development constrains SME growth more severely and, therefore, an improvement in financial development should be expected to have a greater impact in provinces where SMEs have a higher presence. This evidence coincides with the findings of Guiso et al. (2004) from extensive international firmlevel panel data for European Union and transition economy firms. These authors argue that larger firms can raise funds more easily in markets at a distance from their main headquarters ${ }^{20}$.

$>$ Insert here table $5<$

$>$ Insert here table $6<$

The greater impact of bank competition on sales growth in SMEs as compared to large firms may be due to the fact that, as well as being more dependent on bank financing, banks have more incentives to invest in relationship building with SMEs because they are more informationally opaque than large firms. Thus, SMEs are more likely to receive finance in non-competitive loan markets, although above a certain threshold, increases in market power cause slower sales growth. 


\section{Summary, conclusions and policy implications}

This paper analyses the effect of financial development and bank competition on firms' growth from a regional perspective. We take the Spanish case as a testing ground, and combine firm-level information with information on the financial markets in the provinces. The main innovations, given that the database used contains information on the banks each borrower has a relationship with, are that we are able to analyze the effect of provincial bank competition on growth, as well as the effect of the market power of the banks the borrower firm actually deals with. Moreover, as well as following the usual practice of taking bank market concentration as a competition indicator, we use a second competition indicator from the industrial organization literature: the Lerner index. Furthermore, the methodological approach used allows us to estimate Lerner indices separately for the loan market, rather than for all banking activity. Finally, given the availability of provincial-level information, financial variables are measured for the 52 provinces (NUTS3), rather than for the 17 regional administrative territories (Comunidades Autónomas or NUTS2).

Using a model that specifies the mechanism through which finance influences growth, our results show the positive effect of provincial financial development on the economic growth of firms that are more dependent on external finance. We estimate that the impact of provincial financial development on the growth of Spanish firms is around 0.6percentage points as a consequence, primarily, of the effect of financial development on the sales growth of small and medium firms (SMEs). This is because large firms have more ready access to finance from other financial institutions or markets from other regions (or even from other countries).

Although we do not find a statistically significant effect of the average provincial banking market competition on firms' sales growth, bank competition does matter for growth. What is relevant for firms' sales growth is not the level of provincial bank competition, but the level of market power held by the banks the firm borrows from. More precisely, results also show that bank monopoly power has an inverted-U effect on firms' growth, suggesting that the positive effect of market power on growth is highest at intermediate values. The effect is heterogeneous among firms in line with the financial dependence of the industry they belong to: firms from sectors that depend more heavily on external finance enjoy a beneficial effect from (moderate) bank market power. This result is consistent with the literature on relationship banking which argues that bank competition can have a negative effect on the availability of finance for more 
informationally opaque firms by reducing the expected benefits of investments in obtaining specific information from clients. Furthermore, the effect of bank competition (and financial development) on firms' growth is more important for SMEs because they are more dependent on bank financing and because the problems that arise from asymmetric information on borrower quality are also more relevant in SMEs than in large firms.

Overall, our results show that in the banking sector, neither perfect competition nor monopoly is the optimal banking market structure from the point of view of economic growth, but rather a situation of intermediate monopolistic competition is the most advantageous. Furthermore, according to conventional wisdom there is a trade-off between financial stability and competition in banking: some market power must therefore be permitted in order to guarantee financial sector stability and, consequently, to promote economic growth.

The results obtained on the effect of financial development and bank competition on firms' growth may reflect, in part, the influence these two variables have on firms' financing constraints. The variable used to proxy economic growth (sales growth) is also used in other papers (Kaplan and Zingales, 1997, Lamont et al, 2001 and Carbó et al. 2006, among others) as an indirect measure of financing constraints (and also as an indirect measure of investment opportunities and cash-flows). From this alternative interpretation of sales growth, our results would suggest that financial development and intermediate levels of bank market power reduce firms' financing constraints.

A policy implication arising from our results, in accordance with other papers at a national level, is the need to promote greater regional financial development. Our results seem to indicate that the exercise of a certain amount of bank market power, given the negative effect on economic growth of excessive competitive rivalry in banking markets, could be beneficial under certain circumstances. However, there is a threshold above which any increases in market power can be detrimental to growth, and for this reason public authorities should ensure that the banking sector does not go beyond this maximum tolerance level.

\section{Notes}

\footnotetext{
*The authors wish to thank four anonymous referees for their valuable comments on this paper, and are also grateful for the financial support of the Fundación Bilbao Vizcaya Argentaria and Instituto Valenciano de Investigaciones Económicas (FBBVA-IVIE Research Program). Joaquín Maudos also
} 
acknowledges the financial support of the Spanish Ministry of Education and Science-FEDER through the research programs SEJ2004-00110 and SEJ2005-02776 and Generalitat Valenciana (ACOMP2007/158).

${ }^{1}$ For small and medium sized banks that are only present in local markets, the relevant market is regional, not national as papers that focus on country comparisons very often tend to assume.

${ }^{2}$ See a survey in Dow and Rodríguez (1997) and also Williams and Gardener (2003) and Dow (1988), among others.

${ }^{3}$ See, among the more recent publications, Hutchinson and McKillop (1990) and Faini et al. (1993).

${ }^{4}$ See, among others, Amos and Wingender (1993), Samolyk (1994), Rodriguez (1998) and Mackay and Molyneux (1996).

${ }^{5}$ As Dow and Rodriguez (1997) point out, factors related to market structure (concentration ratios, number of competitors, etc.) have been analyzed as explanatory variables of regional interest rate differentials.

${ }^{6}$ The other papers estimate a Lerner index for all banking activity as the ratio (price of total assetsmarginal costs of total assets)/price.

${ }^{7}$ For the specification of the cost function and the expression of the marginal costs, see Maudos and Fernández de Guevara (2007). Symmetry and linear homogeneity in input prices restrictions are imposed.

8 Papers that analyze the effect of financial development on growth with disaggregated information at industry level use different measures of economic growth: output, value added, sales, number of firms and firm size. However, at firm level, it is preferable to use sales growth rather than other indicators of firms' growth such as value added. As Guiso et al. (2004) state, value added statistics from balance sheet information suffer from differences in accounting practices and methodologies across firms (countries and sectors), resulting in large measurement errors. Differences in methodologies are less of an issue with sales, which is the least ambiguous accounting concept. Indeed, in our particular case, SABI reports information on sales for a large number of firms

${ }^{9}$ As far as we know, this is the only paper that includes credit cooperatives in the analysis of competition for the Spanish banking sector. Although the aggregate for the Spanish credit cooperative banking sector accounts for only about $5 \%$ of the total market assets, it should be remembered that these entities play an important role in some provinces.

${ }^{10}$ As one of the referees suggests, both measures give different information and both are important. Thus, it is important to know the effect of the overall competition in the market (at provincial level) and also the effect of the market power of the banks with which each borrower has a relationship.

${ }^{11}$ We have verified the representativeness (by provinces) of the sample used. To this end, we compared the provincial distribution of the sample used (in terms of number of firms) with the provincial distribution of the "Central Directory of Firms" (Directorio central de empresas, DIRCE) from the National Institute of Statistics (Instituto Nacional de Estadistica, INE), which includes the universe of companies operating in Spain. The Pearson correlation coefficient between the two provincial distributions is 0.98 . Therefore, the sample is representative by provinces.

${ }^{12}$ As mentioned above, the only information available for each bank at provincial level is the distribution of its branch network.

${ }^{13}$ The differences in the Lerner index are much more pronounced at bank level. Thus, banks with high indices (close to one) coexist with others whose indexes are close to zero.

${ }^{14}$ See, Cetorelli, 1999.

${ }^{15}$ The explanatory power of the estimated model is very small (according to the $\mathrm{R}^{2}$ ). This result is due to the presence of a large firm-specific noise that is absent in the studies that use industry data as a result of aggregation. For example, Guiso et al. (2004) also report $\mathrm{R}^{2}$ around 0.02 using a large international panel 
of firm-level data for companies in EU and transition countries (32,269 observations). However, their $\mathrm{R}^{2}$ are higher (around 0.36) using industry data.

${ }^{16}$ The values of the Lerner indices are in concordance with values estimated in other papers (around 0.24 in Carbó, López del Paso and Rodriguez, 2003 for the period 1986-99; and 0.23 in Maudos and Pérez for the period 1992-01). Carbó, Fernández de Guevara, Humphrey and Maudos (2005) report similar values of the Lerner index in the loan market.

${ }^{17}$ A further reason why a certain level of bank market power may favor economic growth is due to a possible trade-off between bank competition and financial stability, although the theoretical literature is not unanimous on this issue (see Allen and Gale, 2004).

${ }^{18}$ Results are robust if the sample is split into firms with over 50 employees and those with fewer than 50.

${ }^{19}$ As the effect of financial development and bank competition on sales growth is not statistically significant, table 6 does not report the differential in the real sales growth rate.

${ }^{20}$ We must take into account that our financial development indicator is based only on bank credit. Larger firms usually have access to other sources of financing through the market. 


\section{References}

Allen, F., Gale, D. (2004). Competition and Financial Stability. Journal of Money, Credit and Banking 36, 433-480.

Amos, O.M. and Wingender, J.R. (1993). A model of the interaction between regional financial markets and regional growth, Regional Science and Urban Economics, 23(1): 85-110.

Angelini, P., Disalvo, R., Ferri, G. (1998). Availability and cost of credit for small businesses: customer relationships and credit cooperatives. Journal of Banking and Finance 22, 925-54.

Beck, T., Demirgüç-Kunt, A., Lozaya, N. (2000). Finance and sources of growth. Journal of Financial Economics 58, 261-300.

Beck, T., Levine, R., Loayza, N. (2000). Finance and the sources of growth. Journal of Financial Economics 58, 261-300.

Beck, T., Levine, R. (2005). Legal institutions and financial development. In Handbook of New Institutional Economics, 251-278.

Beck, T., Demirgüç-Kunt, A. (2006). Small and medium-size enterprises: Access to finance as a growth constraint. Journal of Banking and Finance 30, 2931-2943.

Berger, A., Demirgüç-Kunt, A., Levine, R., Haubrich, J. (2004). Bank concentration and competition: an evolution in the making. Journal of Money, Credit and Banking $355,433-451$.

Berger, A., Udell, G. (2006). A more complete conceptual framework for SME finance. Journal of Banking and Finance 30, 2945-2966.

Boot, W. (2000). Relationship banking: what do we know? Journal of Financial Intermediation 9, 7-25.

Carbó, S., López del Paso, R., Rodríguez, F. (2003). Medición de la competencia en mercados bancarios regionales. Revista de Economia Aplicada XI(32), 5-50.

Carbó, S., Humphrey, D. and Rodríguez, F. (2003). Deregulation, Bank Competition and Regional Growth. Regional Studies 37, 227-237. 
Carbó, S. and Rodriguez, F. (2004). The finance-growth nexus, a regional perspective. European Urban and Regional Studies 11, 339-354.

Carbó, S., Fernández de Guevara, J., Humphrey, D., Maudos, J. (2005). Estimating the intensity of price and non-price in banking: an application to the Spanish case, Working Paper BBVA Foundation, DT 05-02.

Carbó, S., López del Paso, R., and Rodríguez, F. (2006). Financial innovations in banking: impact on regional growth. Regional Studies, forthcoming.

Carbó, S., Rodriguez, F., Udell, G. (2006). Bank Market Power and SME Financing Constraints. Proceedings of The 42nd Annual Conference on Bank Structure \& Competition, Federal Reserve Bank of Chicago, 17-19 May, Chicago.

Cetorelli, N. (1999). Competitive analysis in banking: appraisal of the methodologies. Federal Reserve of Chicago, Economic Perspectives, Issue Q1, 2-15.

Cetorelli, N., Gambera, M. (2001). Banking market structure, financial dependence and growth: international evidence from industry data. Journal of Finance 56, 617-648.

Claessens, S., Laeven, L. (2004). What drives bank competition? Some international evidence. Journal of Money, Credit and Banking 36(3), 563-583.

Claessens, S., Laeven, L. (2005). Financial dependence, banking sector competition, and economic growth. Journal of the European Economic Association 3 (1), 179-207.

D’Auria, C., Foglia, A., Reedtz, P. (1999). Bank interest rates and credit relationships in Italy. Journal of Banking and Finance 237, 1067-93.

Dechow, P.M., and Dichev, I.D. (2002). The quality of accruals and earnings: The role of accruals estimation errors. The Accounting Review 77, 35-59.

Dell'Ariccia, G., Marquez, R. (2004). Information and bank credit allocation. Journal of Financial Economics 72(1), 185-214.

Dow, S.C. (1988). Incorporating money in regional economic models. In f. Harrigan and P. McGregor (eds.). Recent advances in regional economic modelling. London Papers in Regional Science, 19, London: Pion Press.

Dow, S.C. (1992). The regional financial sectors: a Scottish case study. Regional Studies, 26(7), 619-631. 
Dow, S.C., Rodriguez-Fuentes, C.J. (1997). Regional finance: a survey. Regional Studies 31, 903-920.

Faini, R., Galli, G. and Giannini, C. (1993). Finance and development: the case of Southern Italy', in A. Giovannini (ed.) Finance and development: issues and experience, Cambridge: Cambridge University Press.

Fernández de Guevara, J., Maudos, J. (2004). Measuring welfare loss of market power: an application to European banks. Applied Economics Letters 1113), 833-836.

Fernández de Guevara, J., Maudos, J., Pérez, F. (2005). Market power in European banking. Journal of Financial Services Research 27(2), 109-137.

Fernández de Guevara, J., Maudos, J., Pérez, F. (2007). Integration and competition in the European financial markets. Journal of International Money and Finance 26, 26-45.

Fernández de Guevara, and J., Maudos, J. (2007). Explanatory factors of market power in the banking system. Manchester School, forthcoming.

Freixas, X. and Rochet, J.C. (1997). Microeconomics of banking. MIT Press.

Goldsmith, R. (1969). Financial structure and development. New Haven and London: Yale University Press.

Guiso, L., Jappelli,T., Padula, M., Pagano, M. (2004). Financial market integration and economic growth in the UE. Economic Policy, October, 523-577.

Hutchinson, R.W., McKillop, D.G. (1990). Regional financial sector models: an application to the Northern Ireland financial sector, Regional Studies 24, 421-31.

Kaplan, S., Zingales, L. (1997). Do financing constraints explain why investment is correlated with cash flow? Quarterly Journal of Economics 112, 169-215.

King, R., Levine, R. (1993a). Finance and growth: Schumperter might be right. Quarterly Journal of Economics 108, 717-737.

King, R., Levine, R. (1993b). Finance, Entrepreneurship and Growth: Theory and Experience. Journal of Monetary Economics 32, 513-542.

Lamont, O., Polk, C, Saá-Requejo, J. (2001). Financial constraints and stock returns", Review of Financial Studies 14, 529-54. 
La Porta, R., Lopez-de-Silanes, F., Shleifer, A., Vishny, R.W. (1998). Law and finance. Journal of Political Economy 106, 1113-1155.

Levine, R. (1993). Financial development and economic growth: views and agenda. Journal of Economic Literature XXXV, 668-726.

Levine, R. (1997). Financial Development and Economic Growth: Views and Agenda. Journal of Economic Literature 35, 688-726.

Levine, R., Zervos, S. (1998). Stock markets, banks, and economic growth. American Economic Review 88, 537-558.

Levine, R, Loayza, N., Beck, T. (2000). Financial Intermediation and Growth: Causality and Causes. Journal of Monetary. Economics 46, 31-77.

Mackay, R., Molyneux, P. (1996). Bank credit and regions: a comparison within Europe. Regional Studies 30, 757-763.

Maudos, J., Pérez, F. (2003). Competencia vs. poder de mercado en la banca española. Moneda y Crédito 217, 139-166.

Maudos, J., Fernández de Guevara, J. (2004). Factors explaining the interest margin in the banking sectors of the European Union. Journal of Banking and Finance 28/9, 22592281.

Maudos, J., Fernández de Guevara, J. (2006). Financial development, bank competition and economic growth.Working Paper No. 269, Spanish Savings Banks Foundation, FUNCAS.

Maudos, J., Fernández de Guevara, J. (2007). The cost of market power in banking: social welfare loss vs. cost inefficiency. Journal of Banking and Finance, forthcoming.

Petersen, M., Rajan R. (1995). The effect of credit market competition on lending relationships. Quarterly Journal of Economics 110, 407-443.

Rajan, R., Zingales, L. (1998). Financial dependence and growth. American Economic Review 88, 559-587.

Rajan, R., Zingales, L. (2001). Financial systems, industrial structure, and growth. Oxford Review of Economic Policy 17(4), 467-482.

Rodríguez-Fuentes, C.J. (1998). Credit availability and regional development, Papers in Regional Science, 77(1): 63-75. 
Samolyk, K.A. (1994). Banking Conditions and Regional Economic Performance. Evidence of a Regional Credit Channel, Journal of Monetary Economics, 34: 259-78.

Williams, J., Gardener, E.P.M. (2003). The efficiency of European regional banking. Regional Studies 37, 321-330. 
Table 1. Number of observations in sample

\begin{tabular}{|c|c|c|}
\hline $\begin{array}{l}\text { NACE Rev. } \\
\quad 1\end{array}$ & Industry & $\begin{array}{l}\text { Number of } \\
\text { observations }\end{array}$ \\
\hline 15 & Manufacture of food products and beverages & 880 \\
\hline 16 & Manufacture of tobacco products & 5 \\
\hline 17 & Manufacture of textiles & 232 \\
\hline 18 & Manufacture of wearing apparel; dressing and dyeing of fur & \\
\hline 19 & $\begin{array}{l}\text { Tanning and dressing of leather; manufacture of luggage, } \\
\text { handbags, saddlery, harness and footwear }\end{array}$ & 66 \\
\hline 20 & $\begin{array}{l}\text { Manufacture of wood and of products of wood and cork, except } \\
\text { furniture; manufacture of articles of straw and plaiting materials }\end{array}$ & \\
\hline & & 119 \\
\hline 21 & Manufacture of pulp, paper and paper products & 167 \\
\hline 22 & Publishing, printing and reproduction of recorded media & 265 \\
\hline 24 & Manufacture of chemicals and chemical products & 404 \\
\hline 25 & Manufacture of rubber and plastic products & 287 \\
\hline 26 & Manufacture of other non-metallic mineral products & 406 \\
\hline 27 & Manufacture of basic metals & 182 \\
\hline 28 & $\begin{array}{l}\text { Manufacture of fabricated metal products, except machinery and } \\
\text { equipment }\end{array}$ & 447 \\
\hline 29 & Manufacture of machinery and equipment n.e.c. & 323 \\
\hline 30 & Manufacture of office machinery and computers & 7 \\
\hline 31 & Manufacture of electrical machinery and apparatus n.e.c. & 162 \\
\hline 32 & $\begin{array}{l}\text { Manufacture of radio, television and communication equipment } \\
\text { and apparatus }\end{array}$ & 53 \\
\hline 33 & $\begin{array}{l}\text { Manufacture of medical, precision and optical instruments, } \\
\text { watches and clocks }\end{array}$ & 34 \\
\hline 34 & Manufacture of motor vehicles, trailers and semi-trailers & 165 \\
\hline 35 & Manufacture of other transport equipment & 65 \\
\hline 36 & Manufacture of furniture; manufacturing n.e.c. & 187 \\
\hline 37 & Recycling & 15 \\
\hline 45 & Construction & 1,074 \\
\hline 50 & $\begin{array}{l}\text { Sale, maintenance and repair of motor vehicles and motorcycles; } \\
\text { retail sale of automotive fuel }\end{array}$ & 651 \\
\hline 51 & $\begin{array}{l}\text { Wholesale trade and commission trade, except of motor vehicles } \\
\text { and motorcycles }\end{array}$ & 2,674 \\
\hline 52 & $\begin{array}{l}\text { Retail trade, except of motor vehicles and motorcycles; repair of } \\
\text { personal and household goods }\end{array}$ & 354 \\
\hline 55 & Hotels and restaurants & 333 \\
\hline 60 & Land transport; transport via pipelines & 167 \\
\hline 61 & Water transport & 25 \\
\hline 62 & Air transport & 12 \\
\hline 63 & $\begin{array}{l}\text { Supporting and auxiliary transport activities; activities of travel } \\
\text { agencies }\end{array}$ & 180 \\
\hline 64 & Post and telecommunications & 26 \\
\hline 70 & Real estate activities & 523 \\
\hline 71 & $\begin{array}{l}\text { Renting of machinery and equipment without operator and of } \\
\text { personal and household goods }\end{array}$ & 63 \\
\hline 72 & Computer and related activities & 78 \\
\hline 73 & Research and development & 11 \\
\hline 74 & Other business activities & 415 \\
\hline
\end{tabular}

Source: $S A B I$. 
Table 2. Financial dependence by industry. Average 1997-2003. Large firms

\begin{tabular}{|c|c|c|}
\hline $\begin{array}{l}\text { NACE } \\
\text { Rev } 1\end{array}$ & Industry & $\begin{array}{c}\text { Financial } \\
\text { dependence }\end{array}$ \\
\hline 15 & Manufacture of food products and beverages & 0.391 \\
\hline 16 & Manufacture of tobacco products & 0.303 \\
\hline 17 & Manufacture of textiles & 0.286 \\
\hline 18 & Manufacture of wearing apparel; dressing and dyeing of fur & 0.342 \\
\hline 19 & $\begin{array}{l}\text { Tanning and dressing of leather; manufacture of luggage, handbags, saddlery, } \\
\text { harness and footwear }\end{array}$ & 0.395 \\
\hline 20 & $\begin{array}{l}\text { Manufacture of wood and of products of wood and cork, except furniture; } \\
\text { manufacture of articles of straw and plaiting materials }\end{array}$ & 0.348 \\
\hline 21 & Manufacture of pulp, paper and paper products & 0.247 \\
\hline 22 & Publishing, printing and reproduction of recorded media & 0.394 \\
\hline 24 & Manufacture of chemicals and chemical products & 0.340 \\
\hline 25 & Manufacture of rubber and plastic products & 0.392 \\
\hline 26 & Manufacture of other non-metallic mineral products & 0.378 \\
\hline 27 & Manufacture of basic metals & 0.273 \\
\hline 28 & Manufacture of fabricated metal products, except machinery and equipment & 0.412 \\
\hline 29 & Manufacture of machinery and equipment n.e.c. & 0.350 \\
\hline 30 & Manufacture of office machinery and computers & 0.458 \\
\hline 31 & Manufacture of electrical machinery and apparatus n.e.c. & 0.352 \\
\hline 32 & Manufacture of radio, television and communication equipment and apparatus & 0.407 \\
\hline 33 & Manufacture of medical, precision and optical instruments, watches and clocks & 0.207 \\
\hline 34 & Manufacture of motor vehicles, trailers and semi-trailers & 0.195 \\
\hline 35 & Manufacture of other transport equipment & 0.469 \\
\hline 36 & Manufacture of furniture; manufacturing n.e.c. & 0.363 \\
\hline 37 & Recycling & 0.071 \\
\hline 45 & Construction & 0.477 \\
\hline 50 & $\begin{array}{l}\text { Sale, maintenance and repair of motor vehicles and motorcycles; retail sale of } \\
\text { automotive fuel }\end{array}$ & 0.325 \\
\hline 51 & Wholesale trade and commission trade, except of motor vehicles and motorcycles & 0.383 \\
\hline 52 & $\begin{array}{l}\text { Retail trade, except of motor vehicles and motorcycles; repair of personal and } \\
\text { household goods }\end{array}$ & 0.295 \\
\hline 55 & Hotels and restaurants & 0.478 \\
\hline 60 & Land transport; transport via pipelines & 0.648 \\
\hline 61 & Water transport & 0.511 \\
\hline 62 & Air transport & 0.654 \\
\hline 63 & Supporting and auxiliary transport activities; activities of travel agencies & 0.352 \\
\hline 64 & Post and telecommunications & 0.588 \\
\hline 70 & Real estate activities & 0.674 \\
\hline 71 & $\begin{array}{l}\text { Renting of machinery and equipment without operator and of personal and } \\
\text { household goods }\end{array}$ & 0.656 \\
\hline 72 & Computer and related activities & 0.305 \\
\hline 73 & Research and development & 0.538 \\
\hline 74 & Other business activities & 0.556 \\
\hline
\end{tabular}

Source: SABI and own elaboration 
Table 3. Descriptive statistics of the variables used

\begin{tabular}{|c|c|c|c|c|c|c|c|}
\hline & Mean & Median & Max. & Min. & $\begin{array}{c}25 \text { th } \\
\text { percentil }\end{array}$ & $\begin{array}{c}\text { 75th } \\
\text { percentil }\end{array}$ & Std. Dev. \\
\hline Real growth rate of sales & 0.027 & 0.032 & 8.647 & -5.215 & -0.041 & 0.112 & 0.322 \\
\hline Financial dependence*Financial development & 0.358 & 0.324 & 0.825 & 0.046 & 0.272 & 0.399 & 0.128 \\
\hline Financial dependence*HHI & 0.045 & 0.041 & 0.147 & 0.006 & 0.035 & 0.052 & 0.015 \\
\hline Financial dependence*HHI ${ }^{2}$ & 0.002 & 0.002 & 0.022 & 0.000 & 0.001 & 0.003 & 0.002 \\
\hline Financial dependence*Lerner index of the market & 0.137 & 0.134 & 0.261 & 0.021 & 0.118 & 0.146 & 0.035 \\
\hline $\begin{array}{l}\text { Financial dependence* Lerner index of banks each firm does } \\
\text { business with }\end{array}$ & 0.158 & 0.150 & 0.374 & -0.123 & 0.129 & 0.179 & 0.047 \\
\hline $\begin{array}{l}\text { Financial dependence* Lerner index of banks each firm does } \\
\text { business with }\end{array}$ & 0.027 & 0.023 & 0.140 & 0.000 & 0.017 & 0.032 & 0.018 \\
\hline
\end{tabular}

Source: SABI, INE, AEB, CECA, UNACC and own elaboration 


\section{Table 4. Financial development, bank competition and growth rate of sales. Total firms}

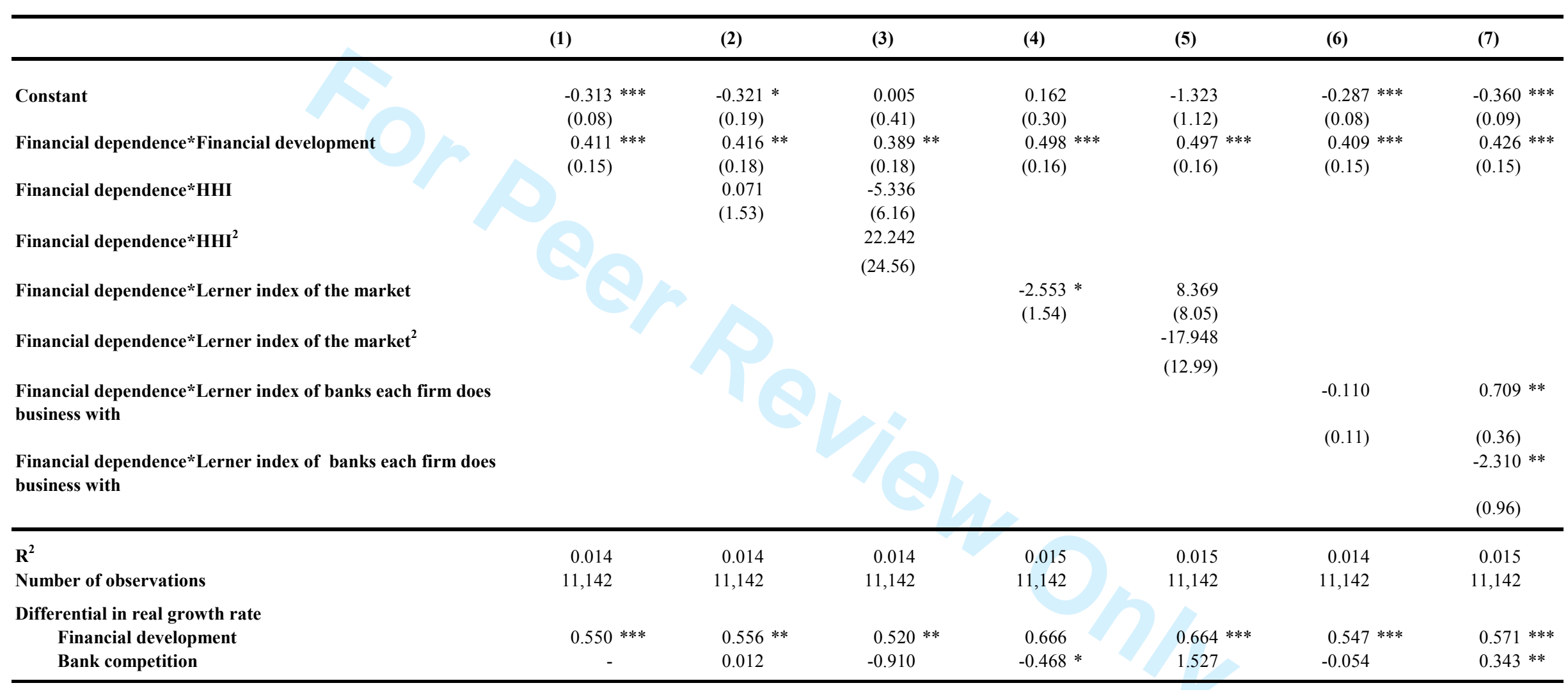

Note: The dependent variable is the annual growth rate of sales for the period 1997-03. The differential in real growth rate measures (in percentage terms) how much faster a firm belonging to a sector at the 75th percentile level of financial dependence grows with respect to a sector at the 25th percentile level when it is located in a province at the 75th percentile of financial development (bank competition) rather than in one at the 25th percentile. All regressions include both province and sector-fixed effects (not reported). * Significant at 10\%; ** significant at $5 \% ; * * *$ significant at $1 \%$. 
Table 5. Financial development, bank competition and growth rate of sales. SMEs

\begin{tabular}{|c|c|c|c|c|c|c|c|}
\hline & (1) & (2) & (3) & (4) & (5) & (6) & (7) \\
\hline Constant & $\begin{array}{l}-0.404 * * * \\
(0.09)\end{array}$ & $\begin{array}{l}-0.436 * * \\
(0.21)\end{array}$ & $\begin{array}{r}0.154 \\
(0.44)\end{array}$ & $\begin{array}{r}0.144 \\
(0.32)\end{array}$ & $\begin{array}{r}-1.723 \\
(1.25)\end{array}$ & $\begin{array}{l}-0.366 * * * \\
(0.09)\end{array}$ & $\begin{array}{l}-0.451^{* * *} \\
(0.10)\end{array}$ \\
\hline Financial dependence*Financial development & $\begin{array}{l}0.513^{* * *} \\
(0.17)\end{array}$ & $\begin{array}{l}0.531 * * * \\
(0.20)\end{array}$ & $\begin{array}{l}0.484 * * \\
(0.20)\end{array}$ & $\begin{array}{l}0.615^{* * * *} \\
(0.18)\end{array}$ & $\begin{array}{l}0.615^{* * *} \\
(0.18)\end{array}$ & $\begin{array}{l}0.511 * * * \\
(0.17)\end{array}$ & $\begin{array}{l}0.533^{* * *} \\
(0.17)\end{array}$ \\
\hline Financial dependence*HHI & & $\begin{array}{r}0.276 \\
(1.65)\end{array}$ & $\begin{array}{r}-9.493 \\
(6.74)\end{array}$ & & & & \\
\hline Financial dependence*HHI ${ }^{2}$ & & & $\begin{array}{l}39.774 \\
(26.59)\end{array}$ & & & & \\
\hline Financial dependence* Lerner index of the market & & & & $\begin{array}{l}-2.953 * * \\
(1.68)\end{array}$ & $\begin{array}{r}10.716 \\
(9.00)\end{array}$ & & \\
\hline Financial dependence*Lerner index of the market ${ }^{2}$ & & & & & $\begin{array}{l}-22.265 \\
(14.41)\end{array}$ & & \\
\hline $\begin{array}{l}\text { Financial dependence*Lerner index of banks each firm does } \\
\text { business with }\end{array}$ & & & & & & $\begin{array}{l}-0.167 \\
(0.12)\end{array}$ & $\begin{array}{l}0.790 * * \\
(0.38)\end{array}$ \\
\hline $\begin{array}{l}\text { Financial dependence* Lerner index of banks each firm does } \\
\text { business with }\end{array}$ & & & & & & & $\begin{array}{l}-2.714 * * * \\
(1.04)\end{array}$ \\
\hline $\begin{array}{l}\mathbf{R}^{2} \\
\text { Number of observations }\end{array}$ & $\begin{array}{l}0.018 \\
9,938\end{array}$ & $\begin{array}{l}0.018 \\
9,938\end{array}$ & $\begin{array}{l}0.018 \\
9,938\end{array}$ & $\begin{array}{l}0.018 \\
9,938\end{array}$ & $\begin{array}{l}0.019 \\
9,938\end{array}$ & $\begin{array}{l}0.018 \\
9,938\end{array}$ & $\begin{array}{l}0.019 \\
9,938\end{array}$ \\
\hline Differential in real growth rate & & & & & & & \\
\hline Financial development & $0.670 * * *$ & $0.692 * * *$ & $0.632 * * *$ & $0.803 * * *$ & $0.803 * * *$ & $0.666 * * *$ & $0.696 * * *$ \\
\hline Bank competition & - & 0.046 & -1.580 & $-0.528 *$ & 1.907 & -0.079 & $0.367 * *$ \\
\hline
\end{tabular}

Note: See table 4 
Table 6. Financial development, bank competition and growth rate of sales. Large firms

\begin{tabular}{|c|c|c|c|c|c|c|c|}
\hline & (1) & (2) & (3) & (4) & (5) & (6) & (7) \\
\hline Constant & $\begin{array}{r}0.076 \\
(0.17)\end{array}$ & $\begin{array}{r}0.255 \\
(0.53)\end{array}$ & $\begin{array}{r}-0.933 \\
(1.07)\end{array}$ & $\begin{array}{r}-0.073 \\
(0.72)\end{array}$ & $\begin{array}{r}1.889 \\
(2.49)\end{array}$ & $\begin{array}{r}0.010 \\
(0.18)\end{array}$ & $\begin{array}{r}0.060 \\
(0.20)\end{array}$ \\
\hline Financial dependence*Financial development & $\begin{array}{r}-0.104 \\
(0.33)\end{array}$ & $\begin{array}{r}-0.194 \\
(0.42)\end{array}$ & $\begin{array}{r}-0.114 \\
(0.42)\end{array}$ & $\begin{array}{r}-0.124 \\
(0.35)\end{array}$ & $\begin{array}{l}-0.118 \\
(0.35)\end{array}$ & $\begin{array}{r}-0.099 \\
(0.33)\end{array}$ & $\begin{array}{r}-0.103 \\
(0.33)\end{array}$ \\
\hline $\begin{array}{l}\text { Financial dependence*HHI } \\
\text { Financial dependence*HHI2 }\end{array}$ & & $\begin{array}{r}-1.641 \\
(4.53)\end{array}$ & $\begin{array}{r}19.076 \\
(16.83) \\
-93.229 \\
(72.95)\end{array}$ & & & & \\
\hline $\begin{array}{l}\text { Financial dependence* Lerner index of the market } \\
\text { Financial dependence*Lerner index of the market2 }\end{array}$ & & & & $\begin{array}{r}0.785 \\
(3.70)\end{array}$ & $\begin{array}{r}-14.069 \\
(18.42) \\
25.826 \\
(31.38)\end{array}$ & & \\
\hline $\begin{array}{l}\text { Financial dependence* Lerner index of banks each firm does } \\
\text { business with }\end{array}$ & & & & & & 0.297 & -0.266 \\
\hline $\begin{array}{l}\text { Financial dependence*Lerner index of banks each firm does } \\
\text { business with }\end{array}$ & & & & & & $(0.26)$ & $\begin{array}{r}(0.97) \\
1.503 \\
(2.51)\end{array}$ \\
\hline $\begin{array}{l}\text { R2 } \\
\text { Number of observations }\end{array}$ & $\begin{array}{r}-0.023 \\
1,204\end{array}$ & $\begin{array}{r}-0.024 \\
1,204\end{array}$ & $\begin{array}{r}-0.023 \\
1,204\end{array}$ & $\begin{array}{r}-0.024 \\
1,204\end{array}$ & $\begin{array}{r}-0.024 \\
1,204\end{array}$ & $\begin{array}{r}-0.023 \\
1,204\end{array}$ & $\begin{array}{r}-0.023 \\
1,204\end{array}$ \\
\hline
\end{tabular}

Note: see table 4 . 
Figure 1. Financial development in the Spanish provinces. Average 1997-2003 (Private credit/GDP). Percentages
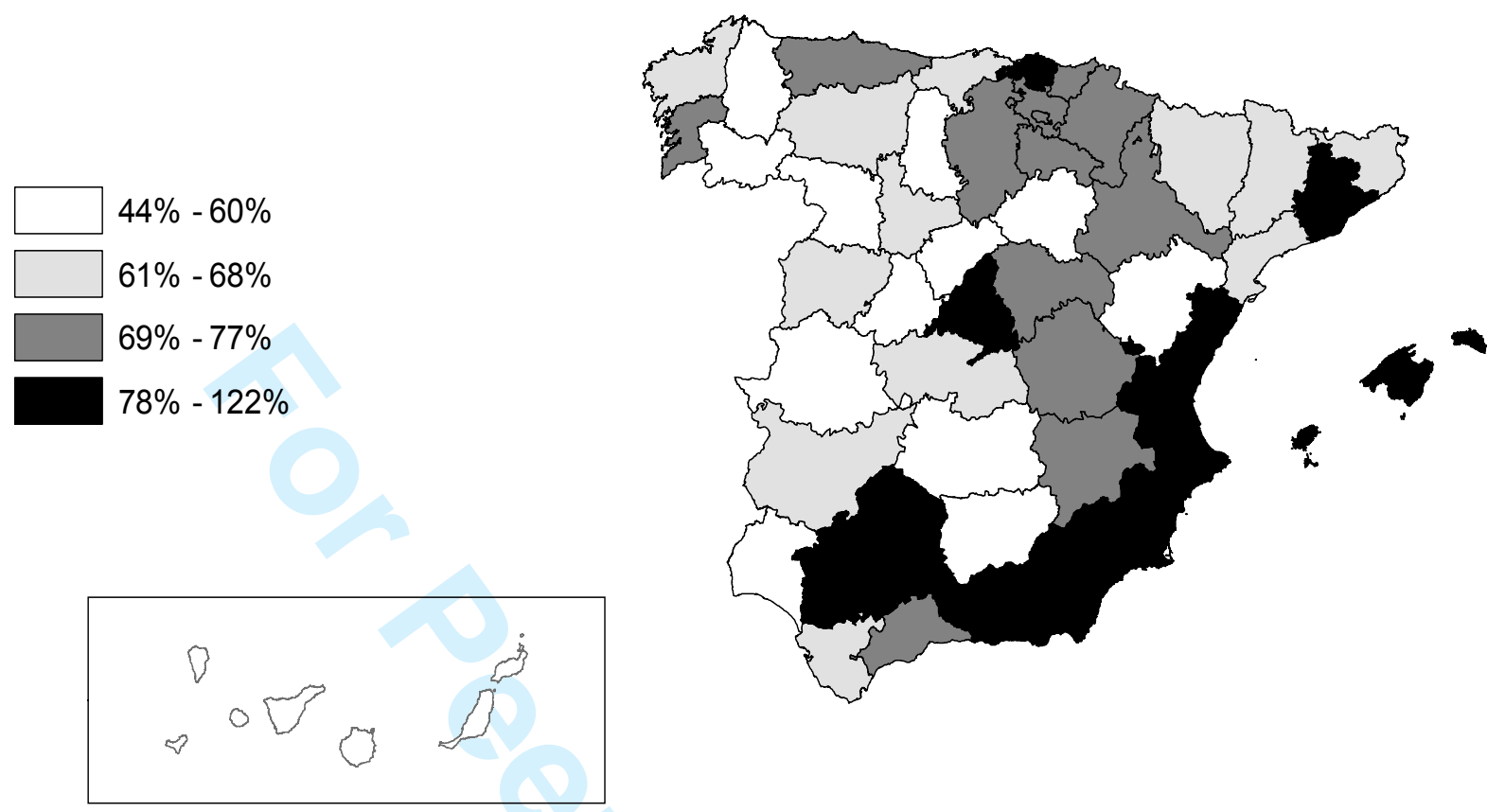

Source: Bank of Spain, INE and own elaboration. 
Figure 2. Lerner indices by provinces. Average 1997-2003.
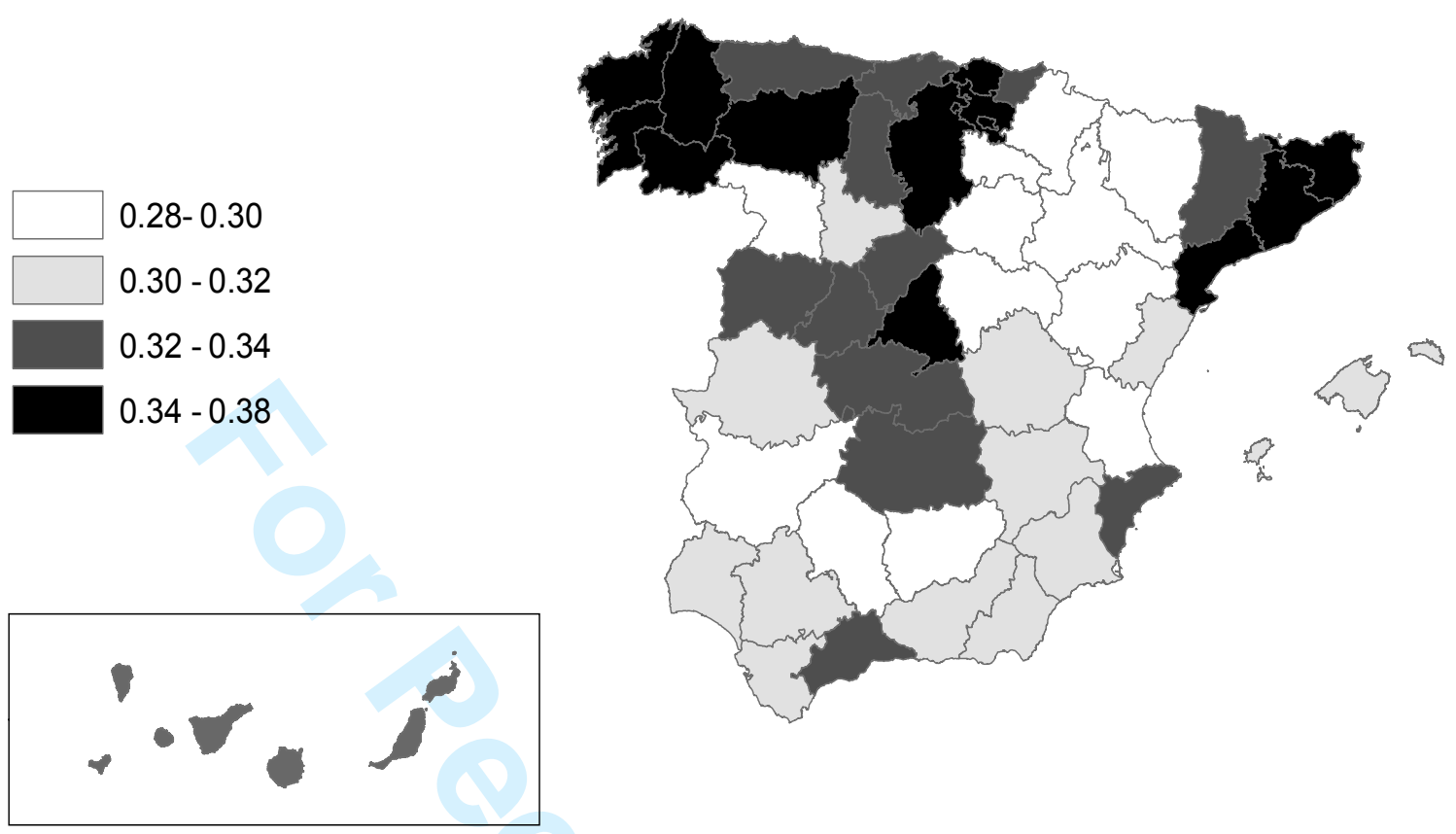

Source: AEB, CECA, UNACC and own elaboration 
Figure 3. Herfindahl-Hirschman index of banking concentration in the Spanish provinces. Average 1997-2003
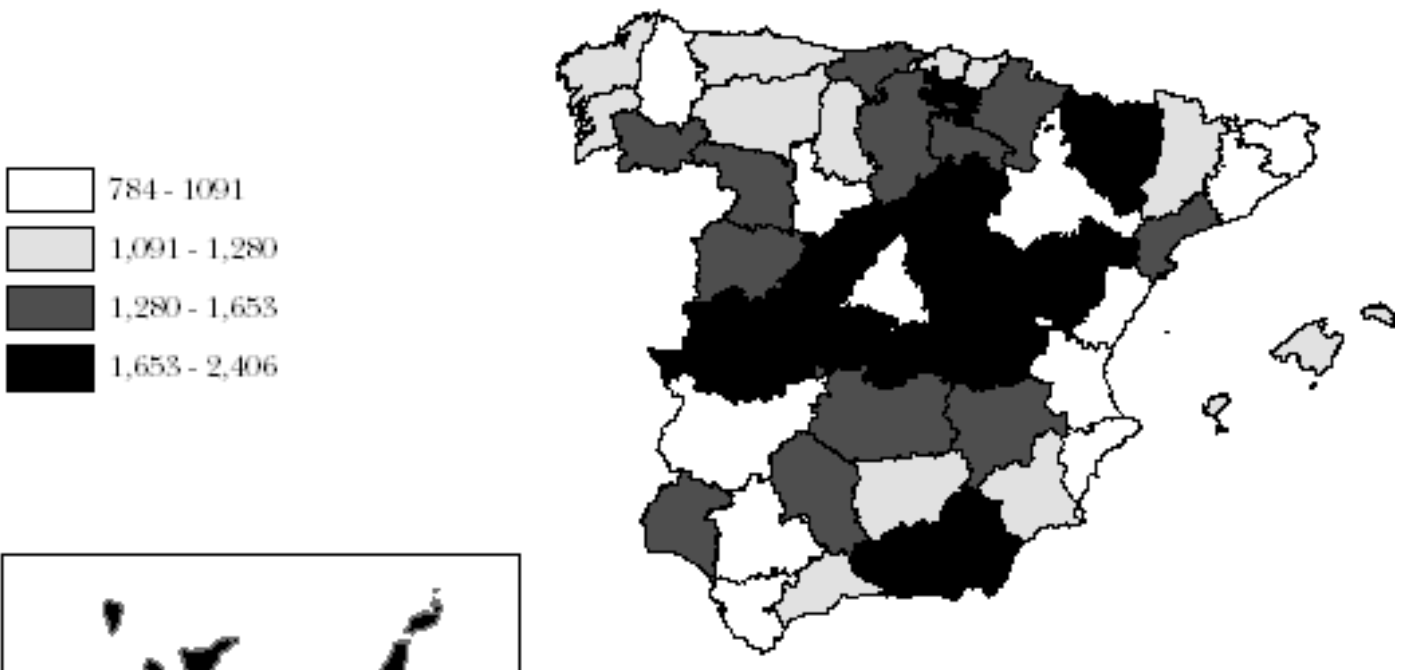

Source: AEB, CECA, UNACC and own elaboration 
Figure 4. The U-shaped relationship between market power and economic growth

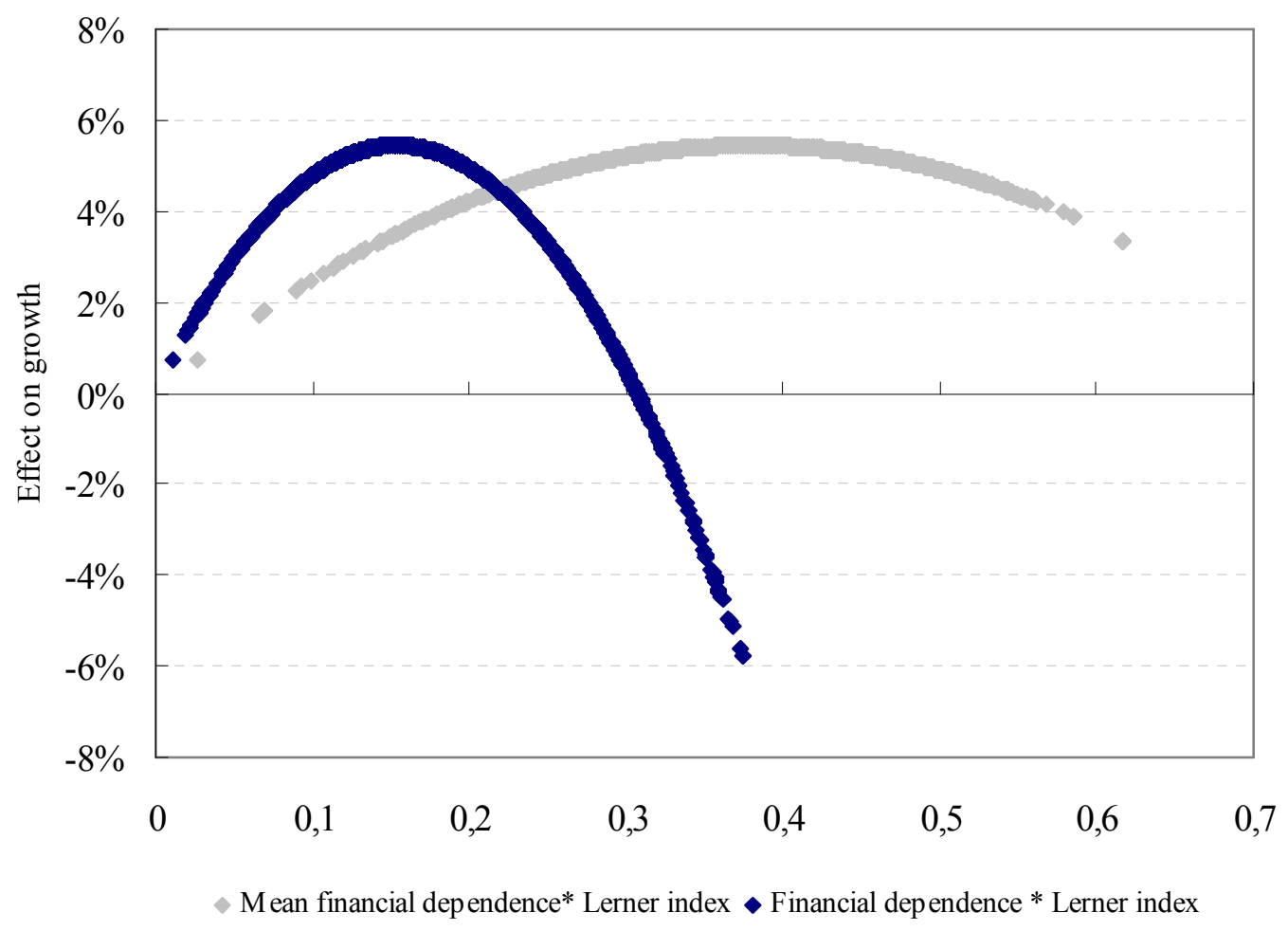

Source: own elaboration. 